\title{
Application of seismic stratigraphy and structural analysis in the determination of petroleum plays within the Eastern Niger Delta Basin, Nigeria
}

\author{
D. O. Anomneze - A. U. Okoro • N. E. Ajaegwu • \\ E. O. Akpunonu $\cdot$ C. V. Ahaneku $\cdot$ T. A. D. Ede \\ G. C. Okeugo $\cdot$ C. F. Ejeke
}

Received: 22 October 2014/ Accepted: 24 February 2015/Published online: 12 March 2015

(C) The Author(s) 2015. This article is published with open access at Springerlink.com

\begin{abstract}
As Nigerian operations expand into more challenging and costly operating environments of deepfrontiers, there is need for critical access to sound stratigraphic, depositional and reservoir facies models. The extraction of facies types from geometric insights and pattern recognition using predominantly $3 \mathrm{D}$ seismic data is a rapidly evolving discipline that facilitates the development of reservoir prediction models linked to significant plays. Play based exploration approach such as this provides the critical link between regional observations and prospect generation. In this study a regional dataset which comprised of a merged 3D seismic volume, well logs, biostratigraphic, biofacies, paleobathymetry and core data from Eastern Niger Delta was interpreted. Results clearly show the overall structural, stratigraphic and architectural styles within the region to ensure that successes achieved in the past can be repeated and also significant advances made to ensure future exploration success. An added outcome is a low-risk exploration workflow that is capable of correctly predicting reservoir rocks to be encountered in a new play and prospect. Three plays have been identified from this study: (1) shelf edge deltas, (2) pinch-out play and (3) hanging wall play. Each play displays a unique morphology, seismic expression, structural configuration, migration pathway, seal integrity and reservoir dispersal pattern. These prediction models provide play based
\end{abstract}

D. O. Anomneze $(\bowtie) \cdot$ A. U. Okoro - N. E. Ajaegwu

E. O. Akpunonu - C. V. Ahaneku - T. A. D. Ede - C. F. Ejeke

Department of Geological Sciences, Nnamdi Azikiwe

University, Awka, Anambra State, Nigeria

e-mail: davanomneze@gmail.com

G. C. Okeugo

Department of Geology, University of Nigeria, Nsukka,

Enugu State, Nigeria exploration targets for areas with similar depositional settings. The successful application of this technique serve to encourage exploration in the Niger Delta Basin by adopting strategies where seismic stratigraphy will be the most likely means to provide drilling targets to more independent operators.

Keywords Seismic stratigraphy $\cdot$ Structural configuration - Pattern recognition · Petroleum plays

\section{Introduction}

The financially, geologically and most attractive petroleum play area in Nigeria today exists in the onshore and offshore Niger Delta region which forms one of the world's major hydrocarbon provinces. Its estimated oil and gas reserves are huge, available technology is constantly improving and a large infra-structure system is available. The exploration of this province has taken place almost exclusively during the past 45 years. The remaining opportunities in the Niger Delta area are mostly either small, shallow, normally pressured but well-imaged targets, or potentially larger, deeper, over pressured and poorly imaged targets (Adereti et al. 2012). Prospecting for deeper targets requires play based prediction models that can be applied to augment the interpretation of poorly-imaged targets.

As Nigerian operations expand into more challenging and costly operating environments, there is need for critical access to sound stratigraphic, depositional and reservoir facies models. One approach to developing these models is through the study of Eocene to Recent systems as analogs for subsurface systems. This paper describes a study of an Upper Oligocene to Eocene sediments between two oil 


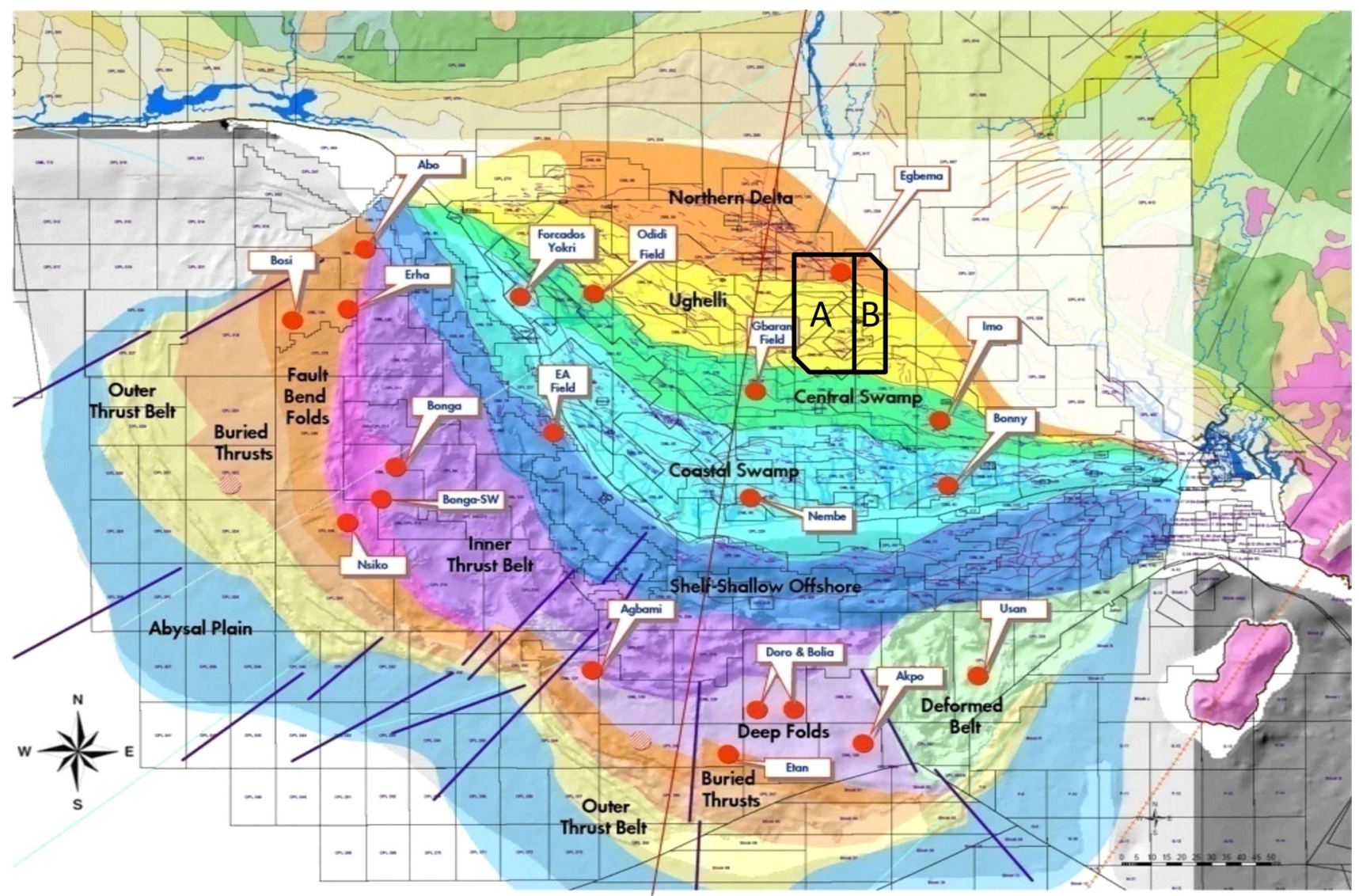

Fig. 1 Location map of the study area (OML A\&B)

blocks OML A\&B (Fig. 1) in the onshore Eastern Niger Delta.

The derivation of stratigraphic insights from seismic data has its origins in the early 1970's with the advent of improved quality 2D seismic data. The discipline of seismic stratigraphy traces its roots to the landmark publication of AAPG Memoir 26, which summarized the work of Peter Vail and his colleagues at Exxon Production Research Company (Vail et al. 1977). The seismic expression of stratigraphic features in a 3D seismic cube depends on which way the data volume is being viewed; vertical transect or horizontal map view.

\section{Geologic and structural setting}

The structural evolution of the Niger Delta is dominated by step-wise progradation during a major regressive phase that continues to the recent. The Niger Delta is subdivided into structural zones characterized by an extensional regime onshore and a contractional regime basinwards. Growth faulting dominates the structural style of the Niger Delta extensional regime and it is interpreted to be triggered by the movement of deep-seated, over-pressured, ductile marine shale and aided by slope instability (Doust and Omatsola 1990). The successive phases of the delta growth form transient depobelts that are bounded by mega-structural growth faults. The study area straddles Greater Ughelli and Northern Delta depobelts. Much of it is in the Greater Ughelli depobelt.

Three macrostructures have been identified over the study area in the Greater Ughelli depobelt. Each macrostructure is characterized by a sandy sequence in the north which becomes shalier to the south. The classic Niger Delta stratigraphic sequence of holo-marine shales (Akata Formation), fluviodeltaic sand-shale intercalation (Agbada Formation) and upper coastal plain sands (Benin Formation) is recognised throughout OML A and B. Some of the regional downto-basin DTB faults within the study area extended from the Older Akata Formation to Younger Benin Formation.

\section{Dataset and methodology}

The study uses a volume of 3D seismic-reflection data that covers $458 \mathrm{~km}^{2}$ and straddle Rivers and Imo state, well 
logs, biostratigraphic, biofacies and paleobathymetry data. In an effort to uniquely classify plays with regards to their stratigraphic and structural implications, four distinct but related aspects of stratigraphy were applied: (1) structural and chrono-stratigraphic framework building (2) seismic attribute analysis (3) seismic facies analysis (4) sequence stratigraphic analysis.

Structural and chrono-stratigraphic framework building

Exploration strategy is to understand the framework of structure and sedimentary strata within a basin well enough to conceive of all the potential trapping situations and to design methods to detecting them. Here we want to understand the structural picture and its relevance to the stratigraphic section and accurately map only the critical faults and horizons and incorporate the results into a geologic model. Seven horizons that corresponds to actual maximum flooding surfaces MFS $(23.2,26.2,28.1,31.3,33.0,34.0$ and $35.9 \mathrm{mfs})$ were interpreted after integrating the seismic with available well logs, biostratigraphic and biofacies data. Sequence boundaries of interest were also picked between these MFSs.

\section{Seismic attribute analysis}

Over the past three decade, we have witnessed new applications of seismic attributes in seismic processing, reflector mapping, fault identification, bright spot identification, frequency loss, thin bed tuning, seismic stratigraphy and geomorphology. Gradually, as geophysicists realized that the additional benefits provided by $3 \mathrm{D}$ seismic will improve stratigraphic interpretation of data; seismic interpreters quickly took advantage of this new insight by studying objects of different geologic origins and their spatial relationships. Not all stratigraphic features of interest are readily apparent in amplitude data (Hart 2013). Various seismic attributes have shown to be useful for detecting stratigraphic features in the data in the same way that some attributes are useful for identifying structural features such as faults (Hart 2013). In this study two unique and significant attributes-RMS amplitude and semblance were utilized in characterizing the reservoirs and identifying fault geometries (Figs. 3, 4). The RMS amplitude is a surface attribute that measures the root mean square of amplitude between two surfaces and it is useful in identifying reservoir extent and geometry. The semblance attribute is a volume attribute which measures the linear coherence of events in a multi-trace window and it is especially useful for identifying discontinuities such as faults and channels.
Seismic facies analysis

This approach uses reflection geometries and amplitudes as seen on vertical transects to define seismic facies that are linked to specific stratigraphic bodies that can be used to make qualitative lithology predictions away from existing well control (e.g., Prather et al. 1998; Colombera et al. 2012). Calibration of seismic facies with well control enhances confidence in the interpretation because seismic facies are unique. Also, it is note-worthy to mention that the continuity and configuration of seismic reflectors changes in a predictable manner from one seismic facies to another. Seismic facies in this research was carried out adopting the Prather et al. 1998 type convention (Figs. 2, 3) and uniquely classifying them from our seismic reflection, $\log$ motifs and sand percentage interpretation. Seismic facies interpretation was carried out based on five primary
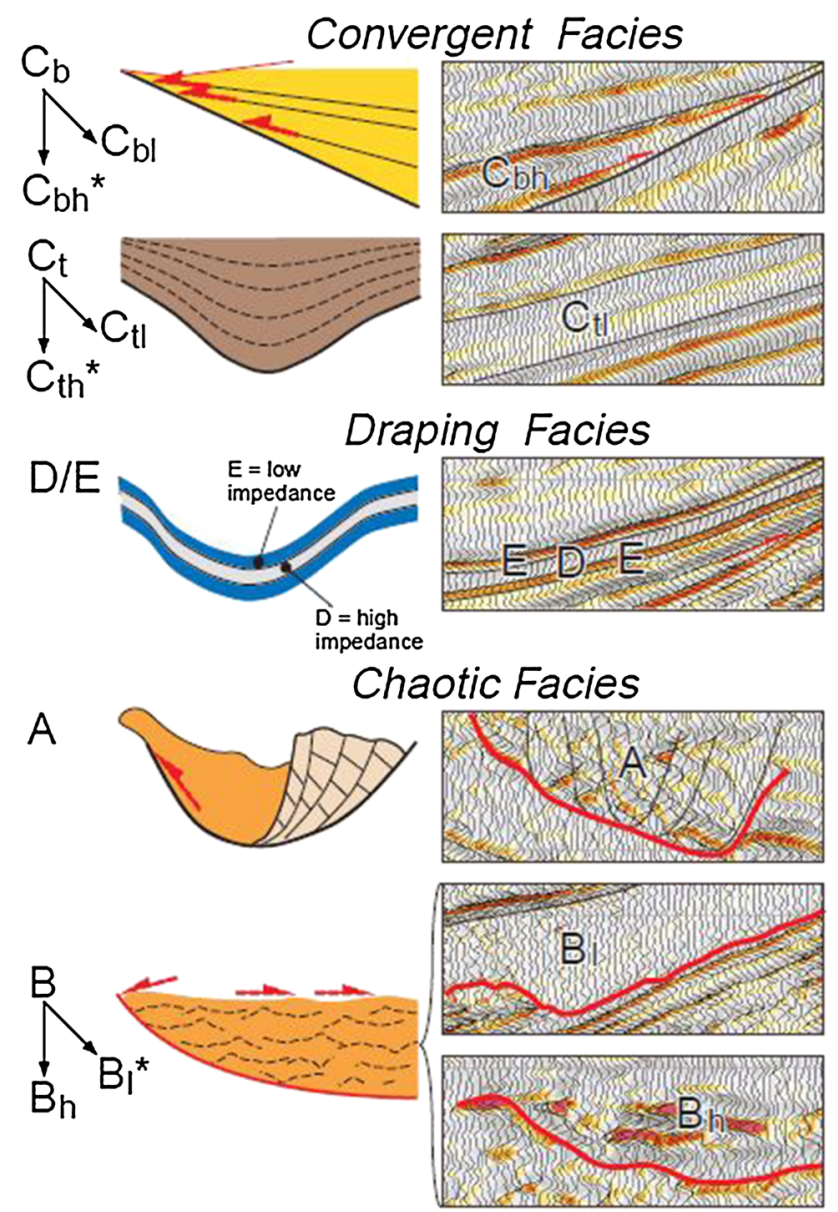

Fig. 2 Seismic facies type convention. $\mathrm{Cbl}$ Low amplitude convergent, $C b h$ high amplitude convergent, $C t$ convergent by thinning at Paleobasin margin, $D \& E$ continuous high and low amplitude, $A$ chaotic with rotated blocks, $B l$ low amplitude discontinuous, shingled to chaotic, $B h$ high amplitude discontinuous, shingled to chaotic (Prather et al. 1998, AAPG (C) 1998 reprinted by the permission of the AAPG whose permission is required for further use) 


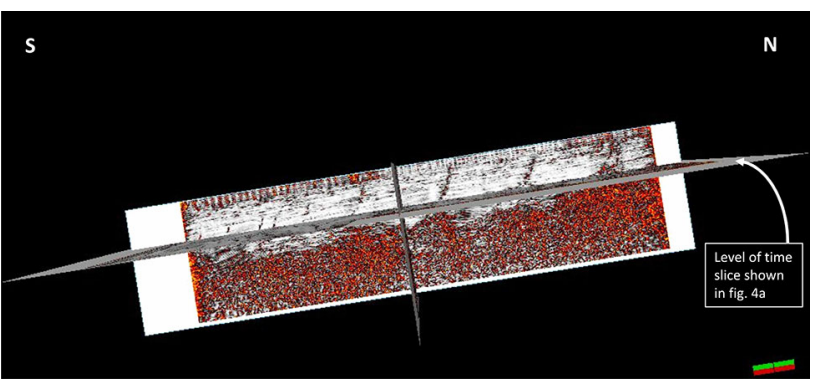

Fig. 3 3D Semblance cube showing the position from which Fig. 4a is sliced at $1828 \mathrm{~ms}$

parameters (reflection amplitude, reflection continuity, reflection configuration, geometry of seismic facies unit, and their relationship with other seismic facies) along key seismic traverses to identify the seismic facies indicative of feeder systems and exploration play facies.

\section{Sequence stratigraphic analysis}

Sequence stratigraphy has proven useful in the identification of critical elements of the petroleum system: reservoir, seal and source rock. It can be a powerful tool when combined with detailed facies, biostratigraphic and paleo- environment analysis to produce predictive framework for reservoir size, distribution and interconnectivity to assist in the building of geological conceptual models.

\section{Results and discussion}

In the Northern part of the two OMLs, the total thickness of paralic sequence is reduced compared to the southern part. The deltaic sequence is extensively affected by syn and post sedimentary normal faults.

The structural interpretation (Figs. 4, 5) from the semblance attribute and the structural framework indicates the presence of major growth faults at and around the boundary between the Northern Delta and Greater Ughelli depobelts. Two regional growth faults were identified towards the northern part of the Greater Ughelli depobelt. These growth faults arise from the effect of short-time over-supply of sediments leading to the formation of depositional centres (Pratsch 1996). However, there are more closely spaced listric faults at the southward section of the depobelt, forming a broad flexure. These faults have been referred to by Evamy et al. (1978) as the ' $\mathrm{K}$ ' type of fault.
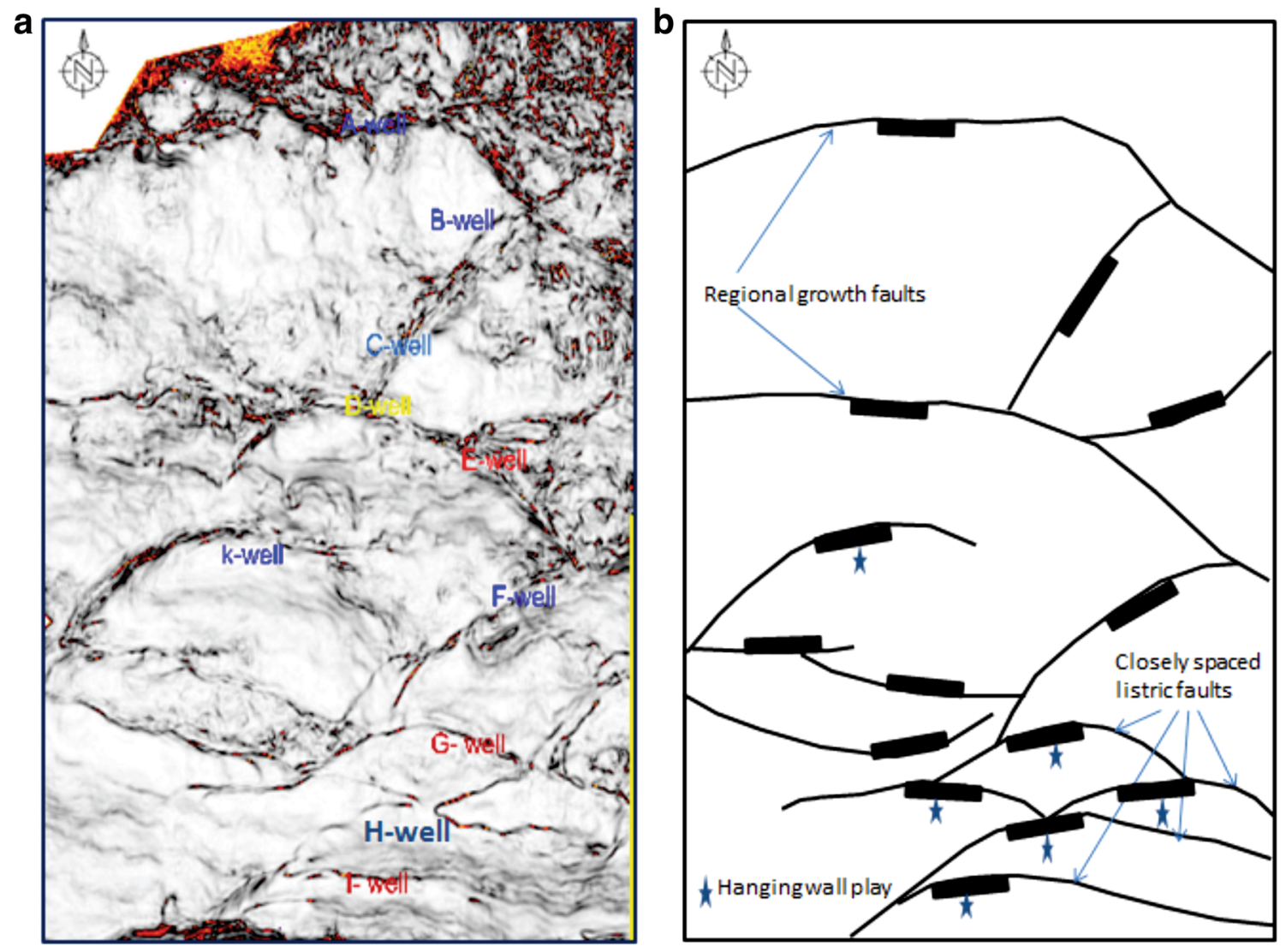

Fig. 4 a Time slice of semblance cube at $1828 \mathrm{~ms}$, b faults interpretation using semblance slice as a guide shows better interpretation and representation of the geometry of the faults 


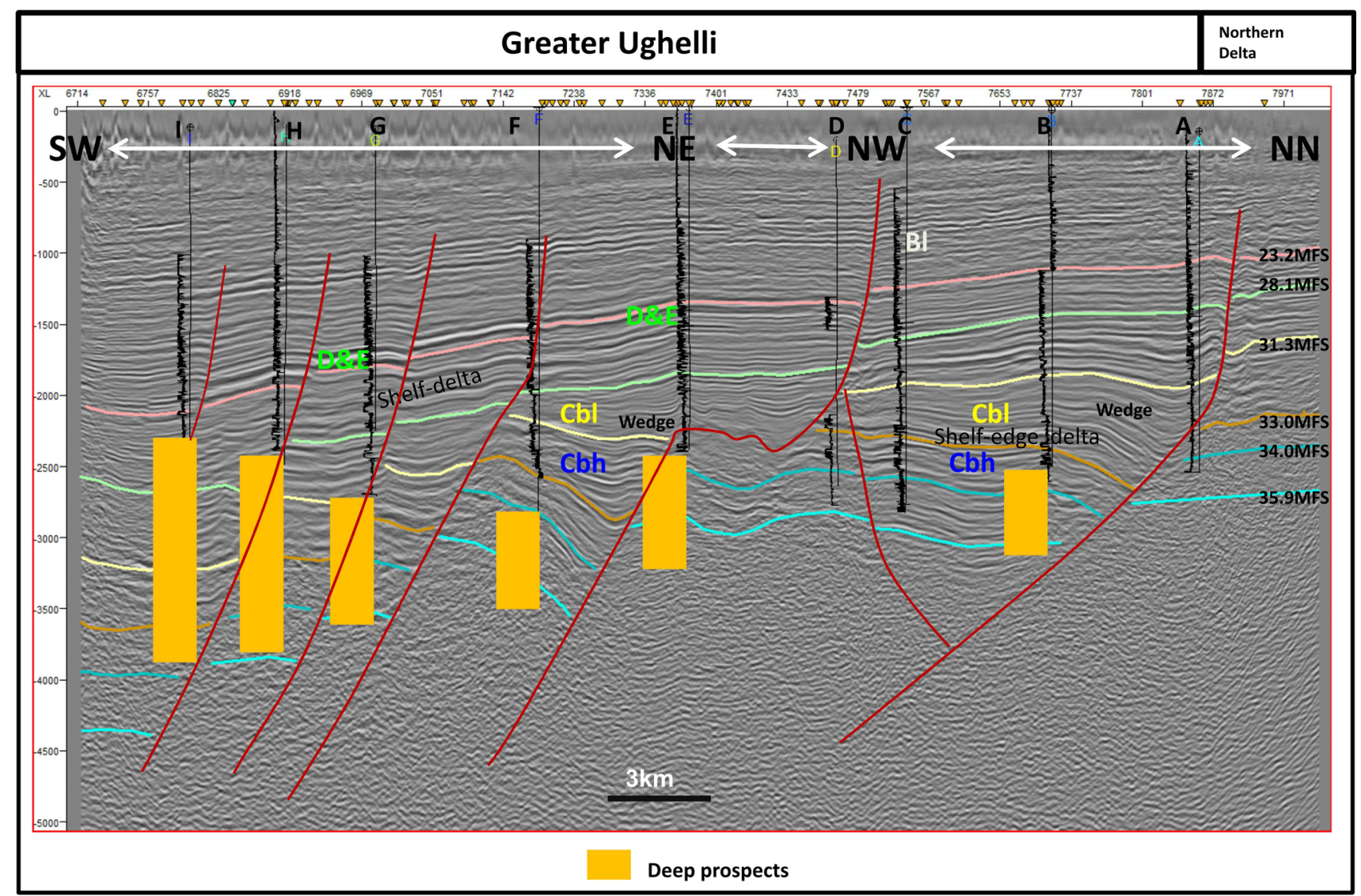

Fig. 5 Structural and chrono-stratigraphic framework (with seismic facies insert)

The RMS Amplitude generated for the interval of $33.0-34.0 \mathrm{mfs}$ identified the geometry of the shelf edge reservoirs (Fig. 6a) and the interval of 31.0-3.0 mfs identified the geometry of the hanging wall reservoir plays (Figs. 6b, 7). The shelf edge reservoirs display aguacate geometry (a proximal slim part growing into a much distal broader part) in map view while the hanging wall reservoirs displays a spherical geometry around the fault in map view.

Calculations of sand percent for the seismic facies permit prediction of reservoir potentials implying that seismic facies with higher sand percentages should conform to exploration targets (Fig. 8).

There is a notable presence of reservoirs (from $\mathrm{Cbh}$ seismic facies) consistently and systematically occurring across the penetrated wells at the base of the uniform subparallel wedge-shaped low amplitude "Cbl" seismic facies. These reservoirs have been delineated to be shelf-edge deltas with their individual thickness ranging from 300 to $500 \mathrm{ft}$. This shelf edge delta interpretation carried out in this study corroborates the earlier work done by Adereti et al. 2012 of which shelf edge deltas continuously prograde into Lowstand reservoirs (Figs. 7, 9).
From the well log sequence stratigraphy interpretation (Fig. 9), the lowstand system tract (LST) deltas are sandier than the highstand system tract (HST) deltas within the 26.2-28.1 ma mfs and $33.0 \mathrm{ma}$ to $34.0 \mathrm{ma} \mathrm{mfs}$ third order sequences. The HST sands thin out basinwards more than the LST sands, particularly, within the shelf edge deltas forming pinch-out geometry.

With the use of the available merged 3D seismic, well logs, paleobathymetry data, biostratigraphic data and core data. A high level subsurface model was created for the study area incorporating the tested major discoveries and a significant play for deep prospects as seen in Fig. 10.

After interpretation and review of the overall structural, stratigraphic and geometric features within the region, to ensure that successes achieved in the past can be repeated and also make significant advances to ensure future exploration success, three plays have been described extensively as discussed below.

\section{Shelf-edge play}

Shelf-edge deltas are a class of deltas developed at or near the shelf edge. Shelf-edge deltas have received much 

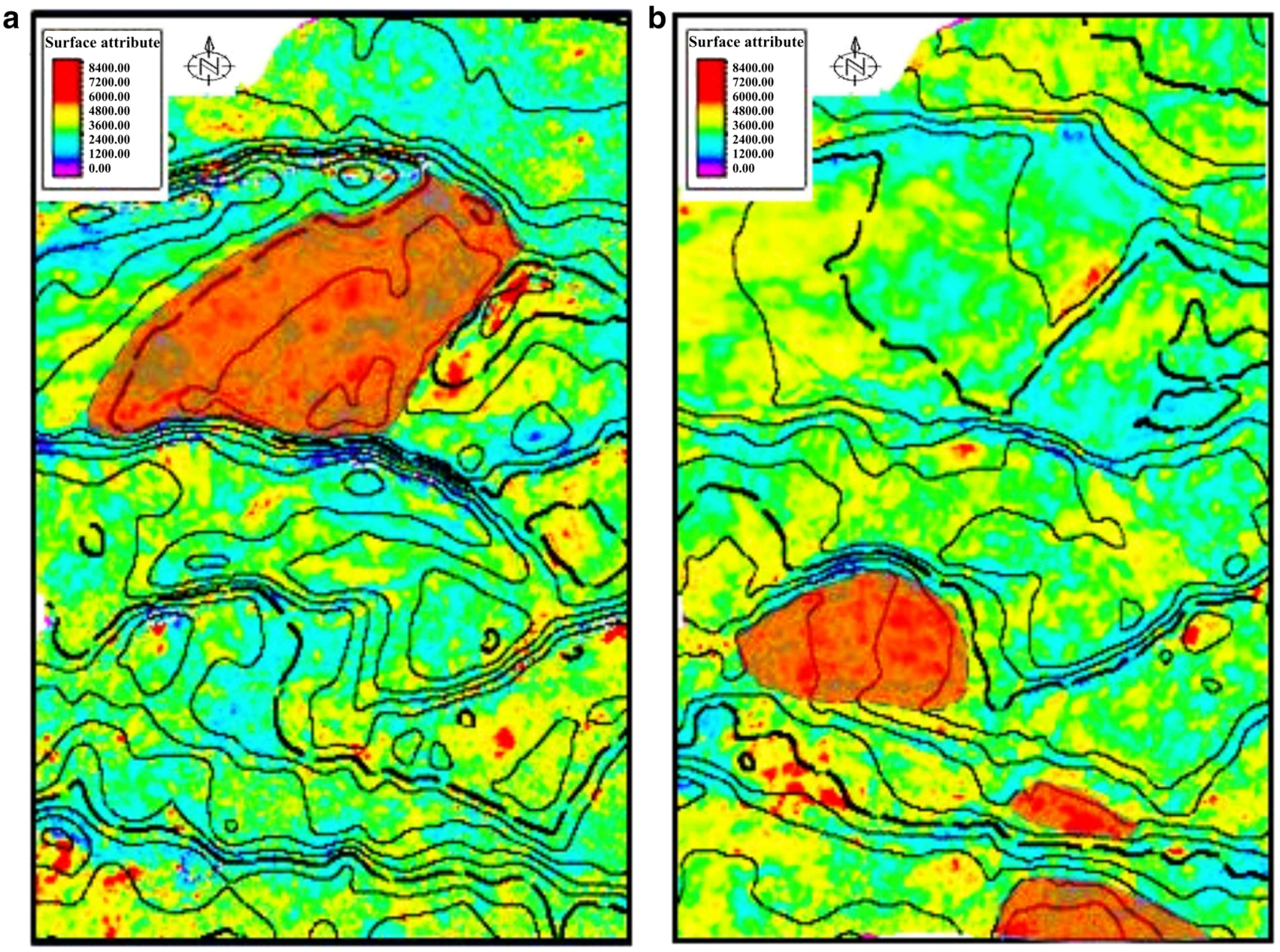

Fig. 6 High RMS Attribute of a 33.0-34.0 ma MFS shows the geometry of the shelf edge delta b 31.3-33.0 ma MFS shows the geometry of the hanging wall plays

attention in recent years because of their role as the staging area for delivery of sediment to deep-water environments, and because of a focus of hydrocarbon exploration in shelfedge settings. They are well known in their geometry and morphology, especially from the Gulf of Mexico shelf margin (e.g., Edwards 1981; Suter and Berryhill 1985; Morton and Suter 1996) and a recent shelf edge in Offshore Nigeria (e.g., Adereti et al. 2012; Fieldman et al. 2013). These cases show clearly that shelf-edge deltas tend to be thicker and show much more evidence of instability and collapse compared to inner shelf deltas. The exposures from outer shelf to upper slope make it possible to analyse the variability of shelf-edge deltas in response to supply variability and to the gradient increase from outer shelf to shelf-edge environments (Dixon et al. 2011). Research by Dixon et al. 2011 showed that river-dominated shelf-edge deltas transport large volumes of sand to the upper slope, even when major shelf-edge incisions are absent.

The opportunity to study a complete shelf edge delta system prompted investigations in the Eastern Niger Delta, including high-resolution seismic studies by research groups at Exxon Mobil. Adereti et al. (2012) reported some results of Exxon Mobil investigation and provided a detailed description of the stratigraphic evolution and bathymetric setting of an Eastern Niger Delta discovery which found a thick stacked $1300 \mathrm{ft}$ of lowstand shelf edge reservoirs below a thick muddy section. Another research on a very large shelf-edge reservoir in the Eastern Niger Delta by the ExxonMobil team according to Fieldman et al. 2013 has shown that three end-member coastlines (wave, tidal, fluvial) exist around shelf-edge regions in the Niger Delta with wave having the most continuity while tidal and fluvial deltas are highly compartmentalized. Their models predicted that wave-dominated shorelines should be most prevalent during lowstands with narrow shelves while tidal shorelines should be most prevalent during highstands with wide shelves. Their prediction was based on core analysis utilizing sedimentary structures and stacking patterns of over $6000 \mathrm{ft}$ of cores from three successive composite sequences. 

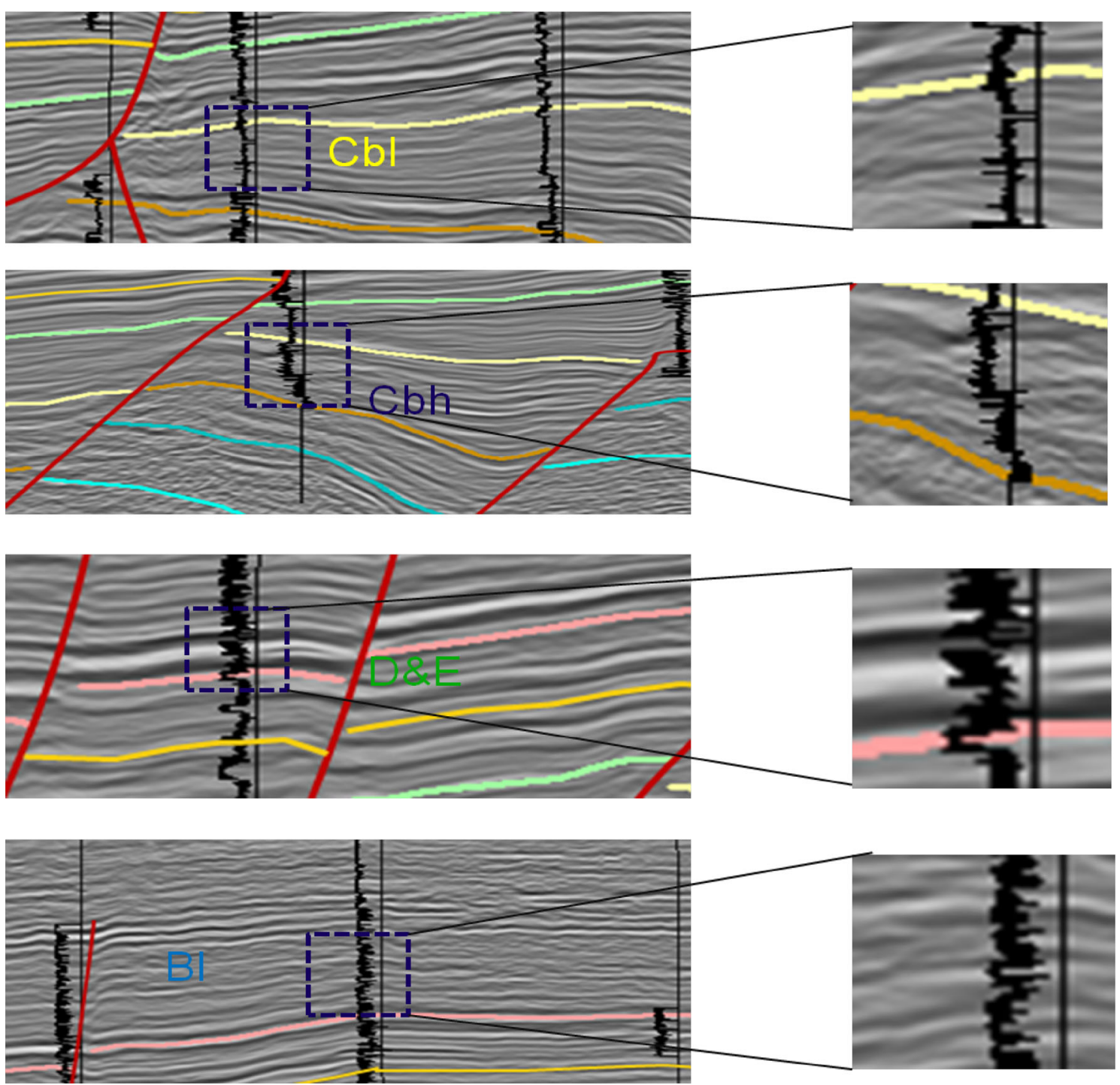

Fig. 7 Seismic facies interpretation with GR wireline log overlay $(C b l$ low amplitude convergent, $C b h$ high amplitude convergent, $D \& E$ continuous high and low amplitude, $B l$-low amplitude discontinuous, shingled to chaotic)

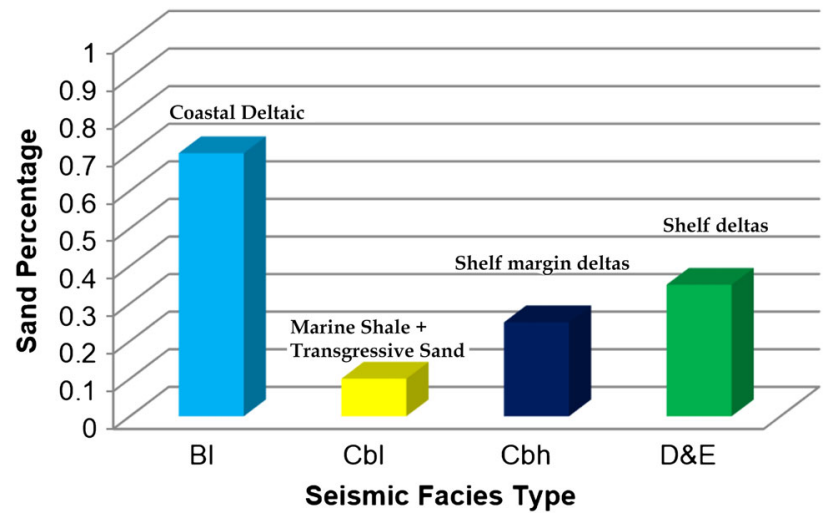

Fig. 8 Seismic facies and their corresponding sand percentages from interpretation
This paper presents data from 3D seismic within the Eastern Niger Delta with different 3D geometry. This data was used to first identify the shelf-edge position geometrically, in combination with paleobathymetry data reflective of Middle Neritic to Outer Neritic and only then to describe the depositional and soft-sediment-deformational facies relative to this position. The shelf edge position was identified around clinoform geometry on a wedge which thins out in the basinward direction. The major deposition of these shelf edge reservoirs were within the Cbh seismic facies and were associated with drags formed by the flexing of the bounding growth faults against counter regional faults which can be seen from the vertical transect of Fig. 5. 


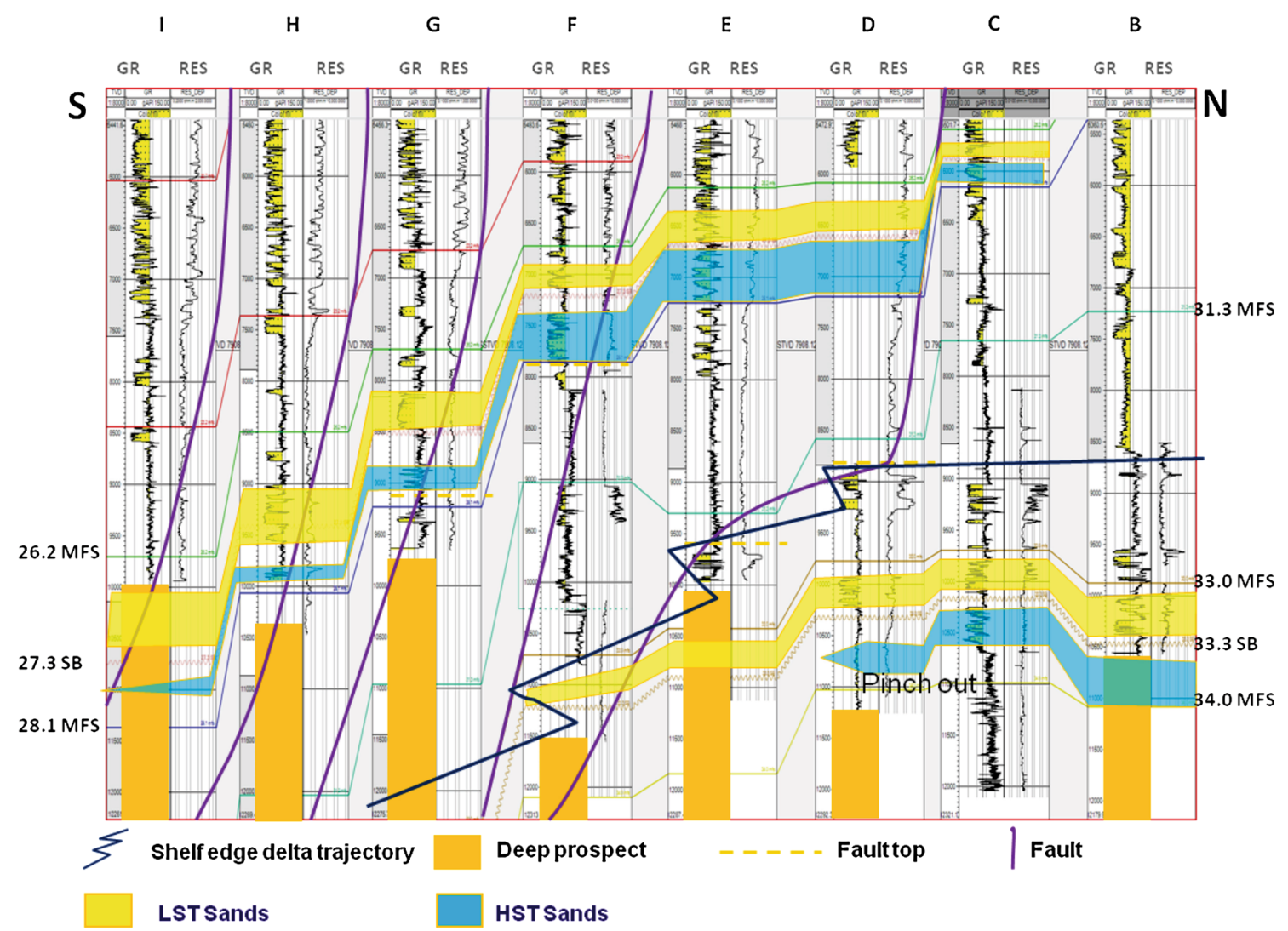

Fig. 9 Well logs stratigraphy showing sequences and selected system tracts reservoir in the Oligocene-Eocene plays of interest

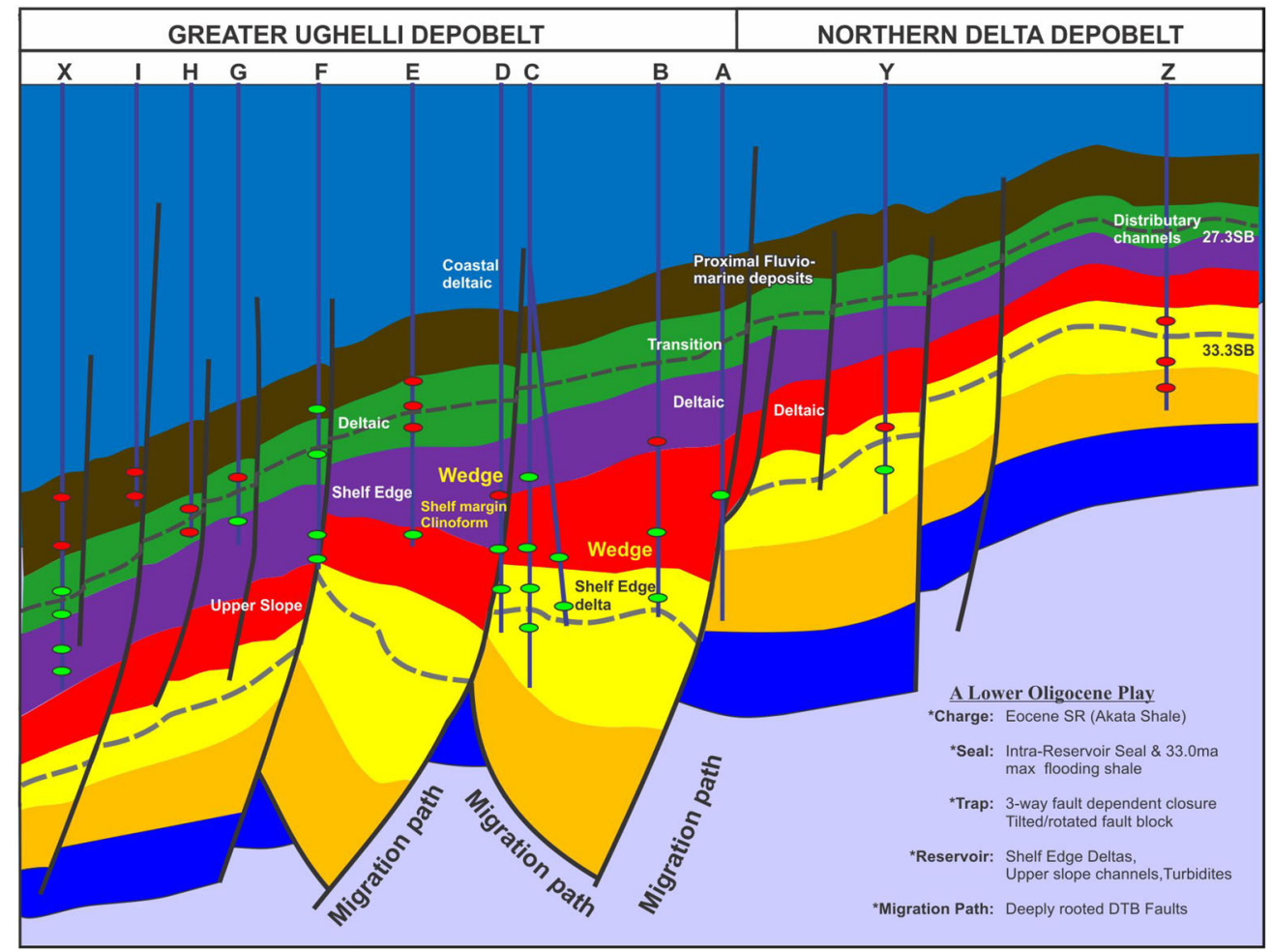

- Tested Major Oil Zones

- Tested Major Gas Zones

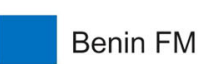

$23.2-26.2 \mathrm{ma}$

26.2 - $28.1 \mathrm{ma}$

28.1 - 31.3ma

31.3 - 33.0ma

33.0 - 34.0ma

34.0 - 35.9ma

35.9 - 36.8ma

Source Rock

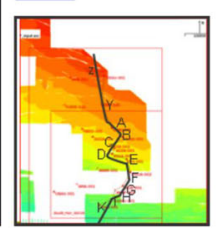

Fig. 10 Play concept: subsurface model of the oligocene-eocene petroleum system in Onshore Eastern Niger Delta 
Fig. 11 Upper oligocene to eocene-deep Eastern Niger Delta petroleum plays

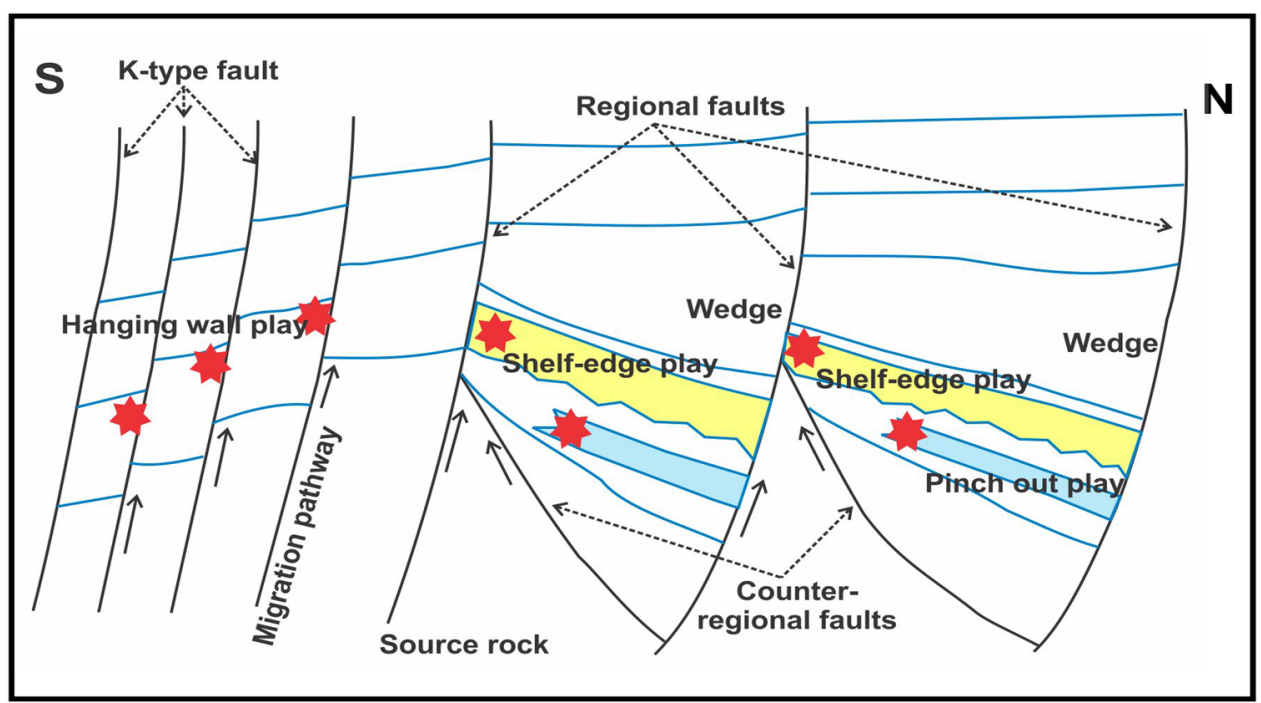

A significant large portion of the shelf in the Northern part of the study area slide downdip as several older faults were suddenly reactivated, plunging the shelf into much basinward position and forming a new shelf edge in a more younger sequence as seen in Figs. 5, 10 and 11.

Calibration of Gamma ray logs with seismic indicate that the wedges in this study are sand-prone mainly at their base within a geometry similar to a structural drag having each reservoir thickness ranging from 300 to $500 \mathrm{ft}$. Each of the lowstand reservoirs is abruptly overlain by thick marine shale that is greater than $1000 \mathrm{ft}$ thick. This is interpreted as a major backstep in the shoreline at the transgressive surface, which separates the underlying lowstand system tracts from the overlying transgressive systems tract. In each case, the sequence is much thicker on the proximal side of the fault than the basinward side forming a wedge shaped geometry. Minor erosion is present at the base of the LST sands, but there are no major incised valleys.

\section{Pinch-out play}

The pinch-out play is a significant play that arises when reflectors pinchout away from areas of sequence thickening. More important are they, when found between a regional growth fault and a counter regional fault. The pinchout geometry is important both in the context of estimating reservoir gross volume and defining pay. In the subsurface, the position of a pinch-out is always an estimate, either by interpolation between wells or a lithological interpretation using seismic data (Hurst et al. 1999). Production test data and production history may contribute to a better understanding of pinch-out geometry (Wardell et al. 1996). The transition from sand-dominated to shale-dominated units, recorded as a pinch-out may comprise a group of stacked, gradually thinning sand units or a group of stacked units that terminate abruptly.

Research by Hurst et al. 1999 has shown that good reservoir quality is inferred to be present almost to the pinch-out limit of sand units, where abrupt termination of beds is associated with infill allowing similar grain size and bed thickness to persist close to the pinch-out.

However, where abrupt termination of beds is associated with onlap, a gradual decrease in grain size is observed, inferring poorer reservoir quality. Moreover, pinch out geometry frequently is discernible on seismic data but after calibration with well $\operatorname{logs}$ there was a clear indication of the presence of a pinch out as shown in Figs. 7 and 9. This pinch out is found within the thick part of wedge shaped reflection geometry around a regional fault (Fig. 9). From sequence stratigraphic relationship the pinch out is predicted to have arised from a high stand system tract being bounded by a sequence boundary at the top and a maximum flooding surface at the base. The shale unit serving as the boundary of termination for the pinch out represents the seal.

\section{Hanging wall play}

Hanging wall traps for Oligocene sands have succeeded in becoming an important play in the Niger Delta. Nevertheless, this play continues to be important with new discoveries being made and this can be expected to continue. Following the basic ideology of petroleum systems that hydrocarbon bearing reservoirs will be on large structural high in the 'right' geographic relationship with a depocentre or structural low. It is expected that the hydrocarbons accumulated inside such a low will have migrated laterally into reservoirs on an adjacent high that lay along a preferred lateral-migration pathway. Such lateral 
hydrocarbon migration will utilize subsurface pressure systems which, in turn are controlled by basinal geometries (Pratsch 1982, 1994). From this study, it was discovered that the location of reservoirs at areas of closely spaced listric fault informally called K-type faults most often occur at the hanging wall just behind the fault plane as blocks become rotated updip into a more landward direction (Figs. 10, 11). Much of this play is expected to be found at the distal end of each Niger Delta depobelt and from this study, they are more characteristic of the Greater Ughelli depobelt.

\section{Conclusions}

Much has been done in recent years of the role that play concepts has to perform in providing critical information to reduce risk in the next generation of exploration targets. The interest still lies on the identification of best sand development intervals in terms of sequence stratigraphy, geometric patterns and seismic facies. This study has aided the identification and description of three plays: (1) Shelf edge play (2) Pinch-out play (3) Hanging wall play. The shelf-edge deltas revealed the preservation of LST stacked sands with thickness of greater than $300 \mathrm{ft}$ each below a wedge shaped facies that is shale-prone. In a vertical transect section this stacked sand thickens more landwards, showing a wedge shaped geometry and a structural drag while in a map view it displays an aguacate geometry showing a broader extent of the reservoir towards the much distal position. This reservoir is bounded by a counter regional fault which also serves as migration pathway with charge from a lower Akata source rock. The pinch out of sand units is predicted to occur when reflectors pinch out away from areas of sequence thickening. Good reservoir quality is inferred to be present almost to the pinch-out limit of sand units and is trapped by inter-reservoir shale as a result of the stratigraphic trapping system and not facies change. The hanging wall trap exists predominantly around closely spaced listric faults at the distal end of a Depobelt. They often arise due to rotation of fault blocks up-dip as sedimentation moves basinward and the associated reservoirs display a spherical shape on map view. The major seal within these plays are the regional maximum flooding surfaces and inter-reservoir shale.

Plays such as those listed above contribute to improving our understanding of a structural and stratigraphic feature of interest. Critical to the success of the approach applied here-into classify these plays lies in the "ground truth" calibration with lithofacies and gross depositional environment. This study reviewed and interpreted the overall structural, stratigraphic, facies and reservoir distribution patterns within the region to ensure that successes made in the past can be repeated and also allow for significant advances to ensure future exploration success.

Open Access This article is distributed under the terms of the Creative Commons Attribution License which permits any use, distribution, and reproduction in any medium, provided the original author(s) and the source are credited.

\section{References}

Adereti O, Feldman H, Unomah G et al (2012) Key elements of a world class petroleum system: lowstand shelf edge reservoirs in the Southeastern Niger Delta, Nigeria. NAPE Bull 24(1):38-42

Colombera L, Felleti F, Mountney NP et al (2012) A database approach for constraining stochastic simulations of the sedimentary heterogeneity of fluvial reservoirs. AAPG Bull 96:2143-2166

Dixon JF, Steel RJ, Olariu C (2011) River dominated, shelf-edge deltas: delivery of sand across the shelf break in the absence of slope incision. Special Publ Int Assoc Sedimentol. doi:10.1111/j. 13653091.2011.01298

Doust H, Omatsola E (1990) Niger Delta in divergent/passive margin basins. In: Edwards JD, Santogrossi PA (eds) Divergent/passive margin Basins. AAPG Memoir, vol 48, pp 239-248

Edwards MB (1981) Upper Wilcox Rosita delta system of south Texas: Growth-faulted shelf-edge deltas. AAPG Bull 65:54-73

Evamy BD, Haremboure J, Kamerling P et al (1978) Hydrocarbon habitat of Tertiary Niger Delta. AAPG Bull 62:1-39

Fieldman H, Adereti O, Ahmed B et al (2013) Predicting large-scale reservoir architecture: application of data from shelf edge reservoirs in the Eastern Niger Delta. NAPE Bull 25(1):52-60

Hart BS (2013) Whither seismic stratigraphy. Interpretation 1(1): SA3-SA20

Hurst A, Verstralen I, Cronin B et al (1999) Sand-rich fairways in deep-water clastic reservoirs: Genetic units, capturing uncertainty, and a new approach to reservoir modelling. AAPG Bull 83(7):1096-1118

Morton RA, Suter JR (1996) Sequence stratigraphy and composition of late quaternary shelf-margin deltas, northern Gulf of Mexico. AAPG Bull 80:505-530

Suter JR, Berryhill HL (1985) Late quaternary shelf-margin deltas, northwest Gulf of Mexico. AAPG Bull 69:77-91

Prather BE, Booth JR, Steffens GS et al (1998) Classification, lithologic calibration, and stratigraphic succession of seismic facies of intraslope basins, deep-water Gulf of Mexico. AAPG Bull 82:701-728

Pratsch JC (1982) Focused gas migration and concentrations of deepgas accumulations, NW German Basin. Erdoel Erdgas Kohle 35:1-20

Pratsch JC (1994) The location of major oil and gas fields: examples from the Andean foreland. J Petrol Geol 17(3):327-338

Pratsch JC (1996) Exploration concepts in the new "sub-salt" play, off- and onshore Gulf Coast Region. AAPG Mid Continent Section Meeting, pp 1-7

Vail PR, Mitchum RM Jr., Thompson S (1977) Seismic stratigraphy and global changes of sea level, part 3: relative changes of sea level from coastal onlap. In: Payton CE (ed) Seismic Stratigraphy-Applications to Hydrocarbon Exploration. AAPG Memoir vol 26 , pp 63-81

Wardell JR, Hayes MR, Burford, SJ et al (1996) A 3D geostatistical model of a turbidite reservoir and validation by pressure transient analysis. European 3D Reservoir Modeling Conference, Stavanger, Norway, SPE 35538, pp 407-418 